\title{
THE PHILOSOPHY OF ARCHITECTURE IN
} ANALYTIC TRADITION: An Enquiry on the
Possibility of the Field and its Themes

\author{
A B S S T R A C
}

The paper focuses on the new field of philosophy of architecture in analytic tradition. The research presented in this paper is part of an ongoing doctoral research concerning the connection between ethics and aesthetics in architecture. The connection between architecture and philosophy is not a novelty. Architectural theory has always looked up to philosophy for inspiration but only recently philosophers have started to study architecture in detail. Architectural theory is still a field that is in search of a better conceptual frame after the failure of the theoretical premises of the Modern Movement and the rise of the "theory speak". Architecture's features as a public art ask for a certain amount of objectivity. The philosophy of architecture in analytic tradition can contribute to a more objective conceptual frame. The principal concerns are familiar to those acquainted with continental philosophy: What makes architecture special among the arts? What is the essence of an architectural work? How we can better define architecture's social mission?, but the way of answering them is different. The ethical dimension of architecture is one of the most debated subjects among architects in recent years. There are several contributions on the connection between ethics and aesthetics in the philosophy of architecture in analytic tradition. They have the potential to have an impact on architectural theory and practice. 
1. The architect should be equipped with knowledge of many branches of study and varied kinds of learning [...]. This knowledge is the child of practice and theory. Practice is the continuous and regular exercise of employment where manual work is done with any necessary material according to the design of a drawing. Theory, on the other hand, is the ability to demonstrate and explain the productions of dexterity on the principles of proportion.

2. It follows, therefore, that architects who have aimed at acquiring manual skill without scholarship have never been able to reach a position of authority to correspond to their pains, while those who relied only upon theories and scholarship were obviously hunting the shadow, not the substance. But those who have a thorough knowledge of both, like men armed at all points, have the sooner attained their object and carried authority with them.

Vitruvius, The Education of the Architect

\section{INTRODUCTION}

Lately there has been an increasing interest in the conceptual study of architecture and its theory, as the new discipline of philosophy of architecture has emerged. As some architects and philosophers question the existence of the field, my article will focus on its possibilities of existence and themes. The study of the connection between architecture, architectural theory and philosophy will show there is a need to develop a conceptual study of architecture and its theory, and it will also lead to the main themes of philosophy of architecture in analytic tradition.

\section{ARCHITECTURAL THEORY}

Compared to other theoretical disciplines architectural theory is harder to pin in an abstract and normative definition. Any attempt to give such a definition will prove inefficient, as it will leave out important parts of the field. A larger definition is possible and it will serve well the purposes of this article: architectural theory is formed of our thoughts regarding the constructed physical surroundings. By accepting this broad definition, a series of characteristics of architectural theory emerge.

Architectural theory is vast and diverse as practical, social and aesthetic aspects are taken into consideration. There are different kinds of speeches from treatises to manifestos, some texts include technical data and show scant interest in theory, while others present social utopia. 
Thoughts on our built environment are not found only in native theory the architectural theory written mostly by architects for their peers. Ideas and concepts concerning the built environment can be found in fields like aesthetics, literature, ethics, political writings, social sciences and others.

Architectural theory, especially the native one, is not as formal as the writings from the humanities. Theory expresses the subjective thoughts of different architects that describe their sources of inspiration.

\section{Architectural theory and architectural practice}

The theory of architecture is connected with the architectural practice and it serves different purposes: it proposes criteria for the practice, it promotes different types of architecture, and it aims to lead the practice to formal change trough the introduction of new concepts from different fields. Although theory is connected with practice there is a certain ambiguity in the influence of theory on the built environment. The debate around theory's influence on practice is polarized by two views: some see theory as a set of reflections that justify ex post facto the built environment, while others see theory as architecture's driver for change and provider of criteria. ${ }^{1}$ The two views are radical and do not fully describe the relationship between practice and theory, although there are examples in the history of architecture that support both views. A third position is also possible, between theory and practice there can be a dialogue that leads to the flourishing of both fields by promoting the advancement of architecture trough the advancement of architectural knowledge.

There are professional associations like the Royal Institute of British Architects (RIBA) who promote a fruitful interaction between theory and practice. RIBA's current thinking on architectural research supports the dialogue between practice and theory. According to Jeremy Till architectural research is ill-defined as three myths have developed. Myth 1 states that architectural research concerns only the architect and the autonomous field of architecture. Myth 2 supports the view that architecture is extremely complex and it should base its research on other fields of knowledge. While myth 1 is too narrow, myth 2 leads to the dissolution of the architectural research. Myth 3 is widely spread as it considers that building is research, by definition every architectural object is unique and original. Though widely spread, myth 3 is questionable because considering building as research does not lead to the acquisition of communicable knowledge. "The buildings as buildings reduces architecture to mute objects. These in themselves are not sufficient as the stuff of research inquiry, we need to understand the processes that led to the object and interrogate the life of the object after its completion." ${ }^{2}$ 
The Dismiss of the Modern Movement and

the Rise of "Theory-Speak"

Architectural theory has always looked up to philosophy for new concepts and different views of human nature. In a lot of cases the concepts and the philosophical views were distorted, as in the case of Spinoza who is considered a romantic. ${ }^{3}$ At the end of the $60 \mathrm{~s}^{4}$ when the failure of the Modern Movement was undeniable, architectural theory started barrowing concepts from the humanities, especially from continental philosophy ${ }^{5}$ (Marxism, semiotics, phenomenology, hermeneutics, critical theory). Those concepts were mostly used as metaphors and inspiration for architectonic design, and were not correct interpretations of concepts from other disciplines.

As more and more concepts were barrowed and used as metaphors, the architectural theory has been criticized for being highly erratic and it has even been denounced as "theory-speak", a "scientific camouflage". The British philosopher Roger Scruton points out the confusion of architectural theory and comments on some faulty interpretations of twentieth century architectural theory like Gideon's interpretation of the theory of relativity from Time and Architecture $^{6}$. The philosopher John Silber coined the term ,theory-speak”. He denounced the verbal description of some stararchitects like Daniel Libeskind as a pretensious and often misleading shell. The architectural theoretician Paul Alan Johnson made similar remarks in the introduction of his book The Theory of Architecture, Concept, Themes\&Practices, he considers that a part of the architectural theory that has emerged after the failure of the Modern Movement can be described as a ,theory talk"7 of architecture - a form of talk that is not about theory but about prestige .

This state of the discipline opens the debate on the purpose of architectural theory: should architectural theory have truth as its aim or should it seek a subjective substitute for it? Krupinska argues that the aim of architectural theory is the search of a subjective substitute for truth - an inspiration for design. She supports her view with examples from the history of architecture and some claims on theory's connection with the practice. The history of architecture shows there are numerous cases in which mistakes made in architectural theory never influenced the practice in a negative way, as they were only sources of inspiration for the design: the architects of the Renaissance misinterpreted the Antiquity yet achieved good design, Le Corbusier made errors in his construction of the Modulor yet designed some of the masterpieces of the Modern Movement and Peter Eisenman's mistakes in interpreting Noam Chomsky's linguistic theory did not lead to poor design. Krupinska shares the anti-intellectual view 
of the phenomenologist theoretician Alberto Perez-Gomez, considering that architecture is not easily represented in theoretical explanations. Architecture is a field where there is a primacy of practice over theory.

Krupinska's examples rightly question the role of the architect's intentions and purposes in judging his works-the 'intentional fallacy'. Monroe C. Beardsley and William K Wissatt argued in a 1946 article 'Intentional fallacy' that reference to the author's intentions doesn't establish the meaning of a text and therefore the author's intentions should play no relevance in literary evaluation. The same point can be made concerning the evaluation of architectural objects: the architect's intentions are not the criteria for judging a work of architecture or establishing its meanings. Don Ihde holds that there is a parallel of the 'intentional fallacy' in the field of technology and design, the 'designer fallacy' - the designer can design all the purposes and uses of a technology or artifact. Architectural objects are complex artifacts and the architect does not have control over all the outcomes of its design. The 'designer fallacy' and the 'intentional fallacy' back Krupinska's examples but do not lead to the conclusion that we should not question the intentions that are expressed by an architect. Architecture is a public art and implies problem solving and moral obligations, unlike literature. The architect's choices have a strong impact on the users of his buildings and he should be able to support his choices with arguments.

The influence of theory on practice is greater if we look at the examples where questionable theoretical claims contributed to poor design. The failure of the Modern Movement was also a failure of its theoretical premises. At the beginning of the twentieth century architects proposed as axioms the fallowing beliefs: buildings are an expression of their function, "honest" design is desirable and it could be achieved by exposing the structure or using materials in their brute state, architecture and social engineering can lead to a better lifestyle and reform the cities. The belief in these axioms and the economical and political context after WW2 led to the failure of the Modern Movement. Its failure was not only the failure of the buildings designed, but it was also about its "axioms" that were not always analyzed carefully. Even the anti-intellectual view of phenomenologists like Krupinska and Alberto Perez-Gomez is a theoretical response to this "axioms" that were adopted all over the world.

I will argue that the aim of architectural theory should not be the search of a subjective substitute for truth. As the built environment has a strong impact on the individuals, architectural theory should aim at a certain amount of objectivity that will leave room to subjective experiences and idiosyncrasies. 
Our built environment plays an important role in our well-being, as vulnerable beings we need shelter but we also have a fundamental need for a pleasing and beautiful place. The need for shelter imposes objective criteria while the need for beauty is usually associated with subjectivity. It is the subjectivity associated with beauty that has supported the view that architectural theory should not aim for truth.

Subjectivity has always been associated with the artistic field of which architecture is part. Architecture stands amongst other types of art because of its features that ask for a certain amount of agreement - objectivity. Architecture is a public art and if one can avoid a painting he dislikes, he cannot do the same about a building. Another peculiar characteristic of architecture is what Scruton describes as its vernacular feature, architecture "exists first and foremost as a process of arrangement in which every normal man may participate, and indeed does participate, to the extent that he builds, decorates or arranges his rooms". Buildings are imposed by needs and desires and so utility is an important feature of architecture. Architecture is highly localized, buildings depend on their context. Architecture depends on building techniques and materials, architectural change is often brought by technical advances. Function, context and materials define the architectural beauty.

Architectural experience is subjective as any aesthetic experience. The subjectivity of the aesthetic experience has caused many philosophers to consider the aesthetic judgment as lacking objectivity. But following Kant I will hold that aesthetic judgment can be objective, therefore aesthetic judgments of architecture can be correct or wrong and we can have meaningful reasons about whether they are so. I propose a "reasonable objectivism" fallowing Elisabeth Schelleckens and Christian Illies \& Nicholas Ray. I will briefly expose the relation between aesthetic experience and judgment from the point of view of "reasonable objectivism". "Reasonable objectivism" will leave room for subjective perception and idiosyncrasies but it will acknowledge that one can reach an agreement upon the quality of some aesthetic features. Aesthetic perception is subjective and it forms the basis of the aesthetic judgment. The aesthetic judgment is a rational process in which we rely on the possibility of considering the object's most important features in order to check our aesthetic perception.

This type of objectivism can explain cross-cultural agreement over the beauty of certain works of art and is backed up by psychological experiments which show that people tend to find some features pleasing over others. Cross- 
cultural agreement is hard to explain from a subjectivist stance, but holding a "reasonable objectivism" we account for subjective preferences, cultural differences and idiosyncrasies while having a frame of acknowledged aesthetic qualities.

Architecture's features and moral requirements as a public art and the possibility of 'reasonable objectivism' of aesthetic judgment support an architectural theory that aims at objectivity. After the dismiss of the theoretical foundations of the Modern Movement and the rise of the "theory-speak" there is still a need for a proper conceptual frame. Philosophy of architecture in the analytic tradition can contribute to the task because of its objective methods that can complement the current architectural theory.

\section{PHILOSOPHY AND ARCHITECTURE}

\section{Architecture and the major philosophical debates}

Over the course of Western Philosophy architecture has been a relatively neglected discipline in the major philosophical debates. Even in the field of aesthetics it has not captured the attention of philosophers like painting and literature. Although architecture has failed to attract sustained and detailed attention, there have been some significant philosophical contributions. Thoughts on architecture are found in a variety of philosophical writings as is shown in the list below:

- comments on some type of building like the Greek temple, in the writings of Aristotle, Plotinus, Saint Augustine, Thomas of Aquinas, Descartes and Bentham;

- the place architecture holds among other types of art forms, in the writings on aesthetics of Batteux, Wolff, Hegel, Schopenhauer;

- small writings concerning architecture's problems like Heidegger's writings on man's dwelling in the world or Goodman's analysis on the way architectural objects refer;

- ample conceptual studies of architecture like Scruton's aesthetics or Harries' book on the ethical function of architecture. ${ }^{9}$

Most of the philosophical writings that have had an impact on the theory of architecture come from the continental tradition. As most architects are not familiar with analytic philosophy I will briefly explain the analytic-continental divide. 


\section{Continental vs. Analytic Philosophy}

Contemporary Western Philosophy is divided between two traditions: analytic and continental. ${ }^{10}$ A good deal of knowledge of the history of philosophy is needed to explain in detail both traditions. For the purpose of this article I will briefly describe these traditions by pointing out the features that are mostly associated with them.

The continental tradition emerged with the Hegelian reactions to Kant and continues today in various strands that can be considered as responses to Hegel, Hegelianism and themes from the Great German Idealism. Among the important figures of continental philosophy there are: Hegel, Marx, Husserl, Heidegger, Hannah Arendt, Foucault, Sartre, Camus, Derrida and others.

The features that are usually associated with continental philosophy are the following:

- The belief that philosophical problems and concepts are constructs of history and culture. The study of a concept implies the study of its historical development.

- The tendency to use rhetorical and figurative language. Continental philosophers search for a poetic vision, for the most inventive description of the world.

This last feature of continental philosophy has attracted a lot of criticism. Opponents consider the language used in continental philosophy obscure, while continental philosophers and their admirers consider the continental way of writing as profound, the poetic language catches the ineffable. ${ }^{11}$

While the term continental refers to a geographic location, the term analytic refers to a method. The analytic tradition is represented by philosophers like Frege, Russell, Wittgenstein, Carnap, Quine, Putnam, Kripke, Rawls, Goodman, Scruton and others.

The analytic tradition is usually associated with the following features:

- The predilection of spare, literal prose and the need to define terms and offer explicit formulation of theses.

- The belief that philosophical problems are timeless and history plays a minor role in their development.

- The emphasis on objectivity and truth. Conceptual issues are examined by identifying and judging the arguments of various views on a topic. 
Writings in this tradition have been labeled as arid and of little interest for the general public. Some have criticized the analytic tradition for its lack of involvement in the community.

The conceptual study of art appeared quite late in the analytic tradition. The first writings on aesthetics date from the $50 \mathrm{~s}$ and $60 \mathrm{~s}$. In the early period of analytic aesthetics, philosophers applied concepts from the major analytical debates to the study of art. Lately the interest in studying the specificity of every art form has increased. Architecture is one of the arts that aesthetics in the analytic traditions has started studying lately.

A series of architects and philosophers embraced the study of architectural aesthetics in the analytic tradition: Roger Scruton, Saul Fisher, Edward Winter, Richard Hill, John Haldane, Christian Illies \& Nicholas Ray, Christian Baumberger, Noël Carroll. As architecture is a public art its conceptual study is not limited to aesthetics and so in the recent period the field of philosophy of architecture in analytic tradition emerged.

\section{Philosophy of Architecture: themes and aims}

The writings of Saul Fisher $(2009,2015)$ and those of Christian Illies \& Nicholas Ray (2014a) define the field of philosophy of architecture in analytic tradition. Illies \& Ray focus on the "traditional" themes of the field like the influence of philosophical ideas and world views on architectural theory, ethics, aesthetics and philosophical positions illustrated in architectural practice. The two authors promote the existence of a strong bond between architecture and philosophy: buildings are in many ways a response to a philosophical approach but they are not only influenced by different philosophical views, they have the power to solve philosophical dilemmas. ${ }^{12}$ Although this position recognizes the complexity of the field of architecture, it is hard to support. Even if architects would solve philosophical dilemmas trough the act of building it will still be hard to read their solution as a building can have several interpretations.

Fisher defines the subfields of philosophy of architecture starting from the questions that a conceptual study of architecture should answer, philosophy of architecture in the analytic tradition would complement the existing interest for continental philosophy and it will bring the benefits of a tailor made approach. The principal questions are familiar to those acquainted with continental philosophy: What makes architecture special among the arts? What is the essence of an architectural work? How we can better define architecture's social mission?, but the way of answering them is different. Fisher lists the following subfields: 


\section{Architecture and its features}

Architecture can be described in terms of the discipline, architecture is what architects do and we can define the field by pointing at their works. We can also define architecture by pointing to its features or analyzing the architectural objects. Every approach has its drawbacks.

The theory of architecture has two traditional brands of essentialism. According to some architecture's essential features are the Vitruvian qualities of utilitas, venustas and firmitas. Another type of essentialism states that function is at the heart of architecture.

Against these essentialist viewpoints of architecture we can argue that we still don't have the right list of essential features or that a nominalist view is better considering the diversity found among architectural objects.

\section{Metaphysics of architecture}

The metaphysics of architecture is concerned with the fallowing topics: the nature of architectural objects and their properties and types, the relation of architectural parts and wholes and the architectural causality.

\section{Architectura 7 language}

The idea that there is an architectural language dates back to Vitruvius. Architectural language has been compared with the natural language and several arguments have been given, but do natural language and architectural language really resemble? As there is a difference in their semantics and syntax we may consider the link between them as a metaphor.

\section{The formalism and anti-formalism debate}

The debate is focused on the properties of architectural objects that lead to aesthetic properties. Architectural formalism states that form leads to aesthetic properties while anti-formalists consider other features like context.

Architectura 7 experience, knowledge and appreciation

This subfield has familiar topics for architects acquainted with philosophical aesthetics in continental philosophy. Roger Scruton wrote one of the most important contribution to architectural aesthetics of the twentieth century.

Architectural ethics

Architectural ethics includes a multitude of topics: professional ethics, environmental ethics, the study of the interaction of different values and others.

\section{Social and political features of architecture}

Topics in this subfield concern subjects like architecture's autonomy or the architect's political involvement. 
In some of the subfields proposed by Fisher there is not an ongoing debate between architectural theory and analytic philosophy but "traditional" subjects from aesthetics and ethics can become the focus of the new field of philosophy of architecture. There are already several significant contributions to the study of the connection between ethics and aesthetics in architecture. Taylor and Levine studied several concepts concerning the ethical dimension of architecture. Noël Carroll and Christian Baumberger have discussed the possibility of applying the views of moderate moralism to architecture while Illies \& Ray have supported a right to accessible beauty. The conceptual study of the interaction between ethics and aesthetics has the potential to influence the architectural practice and theory as lately architects started questioning their roles in the community.

\section{CONCLUSION}

Architectural theory is still a field that is in search of a better conceptual frame after the dismiss of the Modern Movement and the rise of the "theory speak". Architecture's features as a public art ask for a certain amount of objectivity. The philosophy of architecture can contribute to a more objective conceptual frame because of the nature of its method. The ethical dimension of architecture is one of the most debated subjects among architects in recent years and there are several contributions on the connection between ethics and aesthetics in architecture in the philosophy of architecture. They have the potential to impact the architectural theory and practice. com/uploads/post/attachment/34/2007_Three_Myths_and_One_Model.pdf [PDF], 31.01.2016, 2007. 2014) 60 s are period when significant changes occur in the theory of architecture. 
as I can. Although the book is in the first place an application of philosophical aesthetics, the confusion of architectural theory seems to me so great that no philosophical enquiry can refrain from engaging with its arguments. I hope to show that the urgent questions which confront the architect are indeed philosophical questions, and that they can be clarified, and sometimes even solved."

The term "theory talk" was coined by Stanley Fish in his 1989 book Doing What Comes Natural Change, Rhetoric, and the Practice of Theory in Literary and Legal Studies. Fish suggests that much of the discourses about theory and academy are not theory but "theory talk"-a form of talk that has acquired prestige. from Standford Encyclopedia of Philosophy: https://plato.stanford.edu/entries/architecture/ perspective.html

0 Although contemporary philosophy is seen as a highly divided field it is hard to delineate between the two traditions for the following reasons:

- some philosophers are hard to label as analytic or continental as in the case of Rorty, Wittgenstein or Cassirer

- the labels continental and analytic refer to different criteria of classification: continental refers to a location while analytic refers to a method

- the distinctive features that are associated with each tradition are not always found in every writing: some analytic philosophers study the history of a concept while some continentals use spare, literal prose.

11 See Carnap's critique of Heidegger's metaphysics in "The Overcoming of Metaphysics through the Logical Analysis of Language"

12 „Architecture itself can be regarded as a way of overcoming philosophical tensions by suggesting practical possibilities, namely designs that appear to bridge between rival theories and approaches. Design is in fact the core human discipline, being the only activity that properly involves the imaginative conception of ideas, leading to artifacts that are realised as actual constructions in the world. Thus architects are, uniquely, in a position to fashion buildings and spaces that, at least in the interpretation of some can offer resolutions to the dichotomies and tensions that are endemic to philosophy", Christian Illies\&Nicholas Ray $(2014,146-147)$ Moralism.” Architecture Philosophy vol $1 \mathrm{nr}$ 2, (2015).

Capdevila-Werning, Remei. Goodman for Architects. Routledge, [Kindle format], 2014.

Carroll, Noël. "Architecture and Ethics: Autonomy, Architecture, Art." Architecture Philosophy vol $1 \mathrm{nr} 2$ (2015).

Fisher, Saul, "Architectural Aesthetics in the Analytic Tradition: A New Curriculum.” The Journal of Architectural Education, nr 54, (2009).

Fisher, Saul. "Philosophy of Architecture", The Stanford Encyclopedia of Philosophy (Fall 2015 Edition), Edward N. Zalt , 2015

Goodman, Nelson. "How Buildings Mean" in Critical Inquiry, vol 11, nr 4, pag 642-653, 1985.

Goodman, Nelson Languages of Art: An Approach to a Theory of Symbols, Hackett Publishing, Indianapolis, 1968.

Goodman, Nelson. "On Capturing Cities" in The Journal of Architectural Education, vol 25, nr 1,1991

Goodman, Nelson. "Ways of Worldmaking”, ed Hackett Publishing Company, Indianapolis, 1978. Harries, Karsten. The Ethical Function of Architecture. New York: MIT Press, 1996. 
Hays, Michael K. Architecture Theory since 1968. New York: MIT Press, NY, 1998.

Hill, Richard Design and their consequences, Ed Yale University Press, New Haven and London, 1999.

Ihde, Don. "The Designer Fallacy and Technological Imagination." Philosophy and Design From Engineering to architecture, Pieter E Vermaas, Peter Kroes, Andrew Loght \& Steven A Moore (ed), Springer, 51-61, 2008.

Illies, Christian \& Ray, Nicholas. "'An Aesthetic Deontology: Accesible Beauty as a Fundamental Obligation of Architecture." Architecture Philosophy, vol 1, nr 1 (2014).

Illies, Christian\&Nicholas Ray. Philosophy of Architecture. UK: Cambridge University Press, 2014.

Johnson, Paul-Alan. The Theory of Architecture, Concept Themes\&Practices, New York: Wiley, 1994.

Leach, Neil. Rethinking Architecture: A Reader in Cultural Theory, 2nd edition. New York: Routledge, 2005.

Kruft, Hanno-Walter. A History of Architectural Theory: From Vitruvius to the Present. New York: Princeton: Princeton Architectural Press, 1994.

Krupinska, Jadwiga, What an architectural student should know?, London: Routledge, 2014.

Mallgrave, Harry Francis. Modern Architectural Theory: A Historical Survey, 1673-1969. Cambridge: Cambridge University Press, NY, 2005.

Scruton, Roger. The Aesthetics of Architecture. London: Methuen\&Co.LTD London, 1980.

Schellekens, Anna Elisabeth. A Reasonable Objectivism for Aesthetic Judgements: Towards 2003 an Aesthetic Psychology, http://sas-space.sas.ac.uk/1056/1/Elisabeth\%20Schellekens\%20-\%20 $\mathrm{PhD}$ \%20Thesis.pdf, 31.01.2016.

Silber, John. Architecture of the absurd: How „,Genius” Disfigured a Practical Art. Quantuck Lane Press, 2007.

Taylor, William M, Michael P Levine. Prospects for an ethics of architecture. Routledge [Kindle format], 2012.

Till, Jeremy. Architectural Research: Three Myths and One Model, https://jeremytill.s3.amazonaws. com/uploads/post/attachment/34/2007_Three_Myths_and_One_Model.pdf [PDF], 31.01.2017, 2007.

W. K. Wimsatt Jr. \& M. C. Beardsley „The Intentional Fallacy” in The Sewanee Review, Vol. 54, No. 3 (Jul. - Sep., 1946), pp. 468-488, 1946.

Winters, Edward. Aesthetics \& Architecture. New York: Continuum International Publishing Group, 2007. 
S A J _ 2016 - 8 - 


\section{FENOMEN TRANSPARENTNOSTI : MAPIRANJE TRANSFORMACIJA GRADSKOG PEJZAŽA - ISTRAŽIVAČKA PITANJA}

\section{Snežana Zlatković}

Cilj ovog članka je da predloži metodološke slojeve razvijene tokom istraživanja za doktorsku disertaciju, koje ispituje uticaj transparentnosti na transformacije grada. Prva dva dela procesa istražuju uticaj transparentnosti dekodiranjem (ne)vidljivih transformacija gradskog pejzaža ka mapiranju fragmenata preseka između individualnih atmosfera. Nakon spajanja aktivnosti statičnih i dinamičnih stanja fenomena transparentnosti, četvrti sloj vrši smenu percepcije približavanjem i udaljavanjem - od grada kao celine, ka njegovim pojedinačnim prostornim vrednostima i specifičnim aspektima. Analiza se završava sa (de)fragmentisanim čitanjem putem crteža kao kritičkog alata za rešavanje prostornih konflikata. Sloj po sloj, preložena metodologija utvrđuje uticaj fenomena transparentnosti na arhitektonski proces projektovanja, kao i njegov značaj za promišljanje i razumevanje problema i potencijala transformacija gradskog pejzaža.

KLJUČNE REČI: TRANSFORMACIJE GRADSKOG PEJZAŽA, TRANSPARENTNOST, FENOMENOLOŠKA REDUKCIJA, (DE) FRAGMENTACIJA, PRESEK

\section{FILOZOFIJA ARHITEKTURE U ANALITIČKOJ FILOZOFIJI: Istraživanje mogućnosti polja i tema}

\section{Becheru Raluca}

Ovaj rad je usmeren na novo polje filozofije arhitekture u analitičkoj filozofiji. Istraživanje predstavljeno u ovom radu je deo istraživanja u okviru doktorske disertacije na temu povezanosti etike i estetike u arhitekturi. Veza između arhitekture i filozofije nije novina. Teorija arhitekture se oduvek ugledala na filozofiju, ali tek nedavno su filozofi počeli da izučavaju arhitekturu detaljnije. Teorija arhitekture je još uvek oblast koja je u potrazi za boljim konceptualnim okvirom nakon neuspeha teorijskih premisa modernog pokreta i uspona „teorijskog govora“. Odlika arhitekture kao javne umetnosti traži određenu objektivnost, te filozofija arhitekture u okvirima analitičke filozofije može doprineti postavljanju objektivnijeg konceptualnog okvira. Ključne teme povezane su sa pitanjima kontinentalne filozofije: šta čini arhitekturu posebnom među umetnostima, šta je suština arhitektonskog dela, kako bolje definisati socijalnu misiju arhitekture, dok je način dolaska do odgovora drugačiji. Etička dimenzija arhitekture je jedan od najčešće diskutovanih tema među arhitektima u poslednjih nekoliko godina, te se došlo do nekoliko argumentovanih zaključaka o vezi između etike i estetike u filozofiji arhitekture u analitičkoj filozofiji, koji imaju potencijal da ostvare uticaj na arhitektonsku teoriju i praksu.

KLJUČNE REČI: FILOZOFIJA ARHITEKTURE, ANALITIČKA FILOZOFIJA, TEORIJA ARHITEKTURE 